\title{
Parasite Fauna of the White-Streaked Grouper (Epinephelus ongus) from the Thousand Islands, Java, Indonesia
}

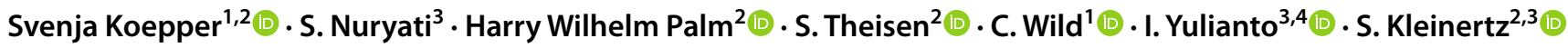

Received: 25 August 2020 / Accepted: 10 November 2020 / Published online: 14 December 2020

(c) The Author(s) 2020

\begin{abstract}
Purpose Fish parasites can cause diseases in humans and lead to commercial losses in fisheries and aquaculture. The objectives of this study were to analyze E. ongus's parasite fauna regarding food safety and parasite transmission risk between Epinephelus species and test whether E.ongus populations can be distinguished by their parasite community.

Methods We studied the metazoan parasite fauna of 30 white-streaked groupers Epinephelus ongus from the Thousand Islands, Java Sea, Indonesia, and compared the parasite community with specimens from Karimunjawa archipelago, Java Sea, from a former study. We used common fish parasitological methods for fish examination and parasite calculations.

Results We found 12 metazoan parasite species, establishing five new host and five new locality records, increasing the known parasite fauna of $E$. ongus by $21 \%$. No anisakid worms infected E. ongus. All but one (trematode Gyliauchen cf. nahaensis) species have been previously reported from Epinephelus. Parasite abundance of E. ongus differed significantly between the two regions.

Conclusions Due to a certain degree of host specificity to groupers, there is potential risk of parasite transmission from E. ongus into groupers in mariculture or surrounding fishes, which increases (sea) food security related health risks from zoonotic parasites and calls for better monitoring and management plans for E. ongus. The regional separation of the Thousand Islands and Karimunjawa with different food availability and fish ecology causes different parasite abundances, distinguishing two separate E. ongus populations by their parasite fauna.
\end{abstract}

Keywords Fish stock separation · Parasite diversity · Gyliauchen cf. nahaensis · Grouper fisheries management · Seafood health risks $\cdot$ Food safety of fisheries products

S. Kleinertz

sonja.kleinertz@uni-rostock.de; sonja_kleinertz@yahoo.de

Svenja Koepper

svenja.koepper@gmail.com

S. Nuryati

sri_nuryati@apps.ipb.ac.id

Harry Wilhelm Palm

harry.palm@uni-rostock.de

S. Theisen

stefan.theisen@uni-rostock.de

C. Wild

christian.wild@uni-bremen.de

I. Yulianto

iyulianto@wcs.org
1 Marine Ecology, Faculty of Biology and Chemistry (FB 2), University of Bremen, UFT, Leobener Str. 6, Room 2160, 28359 Bremen, Germany

2 Aquaculture and Sea-Ranching, Faculty of Agriculture and Environmental Sciences, University of Rostock, Justus-von-Liebig-Weg 2, 18059 Rostock, Germany

3 Department of Aquaculture (S. Nuryati) and Department of Fisheries Resources Utilization (I. Yulianto), Faculty of Fisheries and Marine Sciences (S. Kleinertz), IPB University, Jl. Agatis Kampus IPB Dramaga, Bogor, Indonesia

4 Wildlife Conservation Society Indonesia Program, Jalan Malabar 1 No 11, Kota Bogor, Jawa Barat 16151, Indonesia 


\section{Introduction}

With more than 17, 000 islands and $80,791 \mathrm{~km}$ coastline, Indonesia is the biggest archipelago in the world [1]. Consequently, fisheries and aquaculture play an important role for the national economy [2]. In 2016, behind China, Indonesia ranked second in marine capture production with over 6 million tons [3].

Grouper (Serranidae: Epinephelinae) fisheries is of high economic value for food supply and the live reef fish trade in Indonesia, where they are mainly exported to China, Japan and Singapore [4]. Serranids also contribute to stable livelihoods in developing countries and are important for reef ecosystems as (top) predators [5, 6]. A rising demand for serranids increases fishing effort which drives their risk of extinction [7]. It is estimated that 19 grouper species are threatened and especially the live reef food fish trade remains largely unmanaged [7, 8]. Further knowledge on the ecology and life history of these commercially important species is needed to predict future implications of increasingly high fishing pressure.

Parasites are one of the most successful life forms on Earth [9]. They can impair their fish hosts and also human consumers when raw or undercooked fish is consumed, causing zoonosis as a disease transmitted from animals to humans [10]. The most well-known marine waterborne disease is anisakiasis [11] caused by nematodes of the family Ansiakidae. Monitoring parasites of food fishes is important to continuously assess sea food health risks. Previous studies have suggested a low risk of anisakiasis in Indonesian waters [12-14], but climate change may shift marine boundaries causing different food web compositions in the future $[15,16]$ and there are also other marine helminths with zoonotic potential, e.g., Hysterothylacium or Pseudoterranova [13]. Diverse ecosystems such as Indonesia have huge potential for parasitological research [14]. Parasites provide new insights into fish diet, habitat range and trophic position $[17,18]$ and inform about host ecology due to different infection pathways or accumulation of pollutants $[19,20]$. Consequently, commercially important and often aquaculture species such as the groupers Epinephelus coioides and E. fuscoguttatus have been subject to a number of disease, parasite and environmental studies [19-26].

Today, fishing pressure is shifting toward smaller species such as E. ongus, which is now targeted as food fish in some regions, e.g., Japan [27, 28]. Demand for E. ongus has increased steadily $[28,29]$, also based on landings of E. ongus in Indonesia (Karimunjawa) [28, 30]. With only seven previous studies on the parasite fauna of E. ongus in South-East Asia and Australia [28, 31-36], we herewith sample this fish species from the Thousand Islands archipelago in close proximity to the heavily polluted Jakarta Bay. Our objectives for this study are to assess the transmission risk of parasites from $E$. ongus to cogeners and vice versa and to determine parasite-borne health risks of E. ongus to consumers in terms of food safety and to mariculture fish. Additionally, we aim to test whether E.ongus populations can be distinguished by their parasite community. For that we compare our data to a former study where the parasite fauna of white-streaked groupers (similar in size and weight) was analyzed in Karimunjawa, an archipelago off the coast of Java, Indonesia, in 2013 by Neubert et al. [28] and discuss infection patterns, parasite biodiversity and fish ecology data.

\section{Materials and Methods}

\section{Sample Collection}

From April to June 2018, a total of 30 spearfished Epinephelus ongus were obtained from fishermen in the Thousand Islands archipelago $\left(5^{\circ} 48^{\prime} 07.7^{\prime \prime} \mathrm{S} 106^{\circ} 30^{\prime} 38.4^{\prime \prime} \mathrm{E}\right)$, north coast of West Java, Indonesia (Fig. 1; Table 1). Fish were
Fig. 1 Map of study areas on Java, Indonesia. TI Thousand Islands, $K J$ Karimunjawa (samples taken in 2013 by Neubert et al. [28])

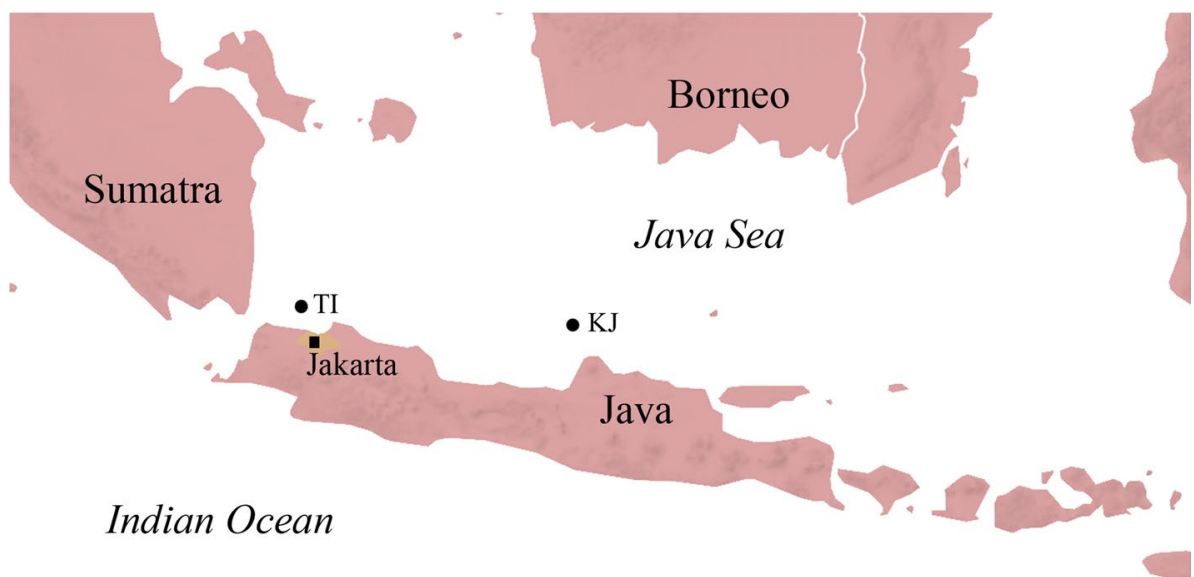


Table 1 Fish biological parameters of Epinephelus ongus from the Thousand Islands and Karimunjawa

\begin{tabular}{|c|c|c|c|c|c|c|c|}
\hline Location & $\mathrm{TL}[\mathrm{cm}]$ & $\mathrm{SL}[\mathrm{cm}]$ & TW $[\mathrm{g}]$ & SW [g] & $\mathrm{m}$ & $\mathrm{f}$ & n.i \\
\hline Thousand Islands & $24.0 \pm 2.8(20.2-30.8)$ & $20.5 \pm 2.4(16.9-26.6)$ & $259.7 \pm 99.5(137.1-525.8)$ & $241.6 \pm 92.8(127.3-494.2)$ & 6 & 24 & - \\
\hline Karimunjawa $^{\mathrm{a}}$ & $25.5 \pm 2.5(20.5-30.4)$ & $21.8 \pm 2.3(17.0-26.2)$ & $266.3 \pm 90.1(108.5-498.0)$ & $238.0 \pm 80.5(99.8-463.6)$ & 23 & 7 & 5 \\
\hline
\end{tabular}

$S L$ standard length, $S W$ slaughter weight, $T L$ total length, $T W$ total weight, $\bar{x} \pm S D$ mean \pm standard deviation, range in parantheses, $f$ female, $m$ male, n.i. not identified

${ }^{\text {a }}$ Data published by Neubert et al. [28] (sampled in May 2013, using the same methods as described for this study)

individually frozen in plastic bags, usually for $2-5$ days, until examination inside the laboratory. Fish were defrosted in lukewarm water and morphometric data were taken (total length, standard length, total weight and gutted weight). Fluids from inside the plastic bags were examined individually under the stereo microscope (Zeiss, Stemi DV4).

\section{Parasitological Examination}

The body cavity was opened and internal organs were removed for subsequent endoparasite examination under the stereo microscope. Fish fillets were examined with translucent light under the stereo microscope. All detected parasites were cleaned from host tissue and collected in $70 \%$ ethanol. Selected specimens were transferred into glycerin on microscopic slides following Riemann [37]. Parasites were identified according to keys and original descriptions. After identification, the parasite specimens were deposited at LIPI, Science Centre, Jakarta-Bogor, Indonesia (Accession numbers: $45,173-181,542,1482-1484$ ).

\section{Processing of Parasitological Data}

Parasitological parameters prevalence $(\mathrm{P})$, intensity (I), mean intensity $(\mathrm{mI})$ and mean abundance $(\mathrm{mA})$ followed Bush et al. [38]. The Shannon-Wiener diversity index [39] and Pielou index of evenness [40] were used to estimate the diversity of the metazoan parasite fauna, as well as the Berger-Parker index of dominance [41]. These indices were calculated for ecto- and endoparasites pooled, and endoparasites exclusively $[22,25,26]$. Ecto- to endoparasite ratio was calculated following Rückert et al. [42].

\section{Statistical Analyses}

All data, including the raw data by Neubert et al. [28], were analyzed using PRIMER software (version 7.0) to compare the parasite fauna of $E$. ongus sampled in this study in the Thousand Islands and sampled by Neubert et al. [28] in Karimunjawa. A total of 65 fish were compared and a similarity matrix was calculated by applying a Bray-Curtis similarity measure. The data for the Bray-Curtis index were transformed (fourth root $=\sqrt{ } \sqrt{ }$ ) prior to analysis. Fish without parasites were omitted from the analysis. A multivariant scaling plot (MDS) was used to display the relation between samples based on similarity matrices. The analysis of similarities (ANOSIM) was used to calculate the level of significance between both data sets. The differences between or within the data groups were given by the $R$ value that ranged from -1 to 1 . An $R$ value of 0 indicated no differences. A value of -1 meant that the identical data point was located outside of the group, whereas with an $R$ value of +1 they were located within the group. The significance level was stated to $p<0.05$. To identify which parasite taxa were responsible for the differences between the examined groups, SIMPER was applied. Additionally, a one-way ANOVA with Student's $T$ test (SigmaPlot Version 11.0) was conducted to determine statistical differences in size of the fish between Karimunjawa [28] and the Thousand Islands.

\section{Results}

\section{Parasite Community}

A total of 12 parasite taxa infested E. ongus from the Thousand Islands. Four Crustacea taxa [Alcirona sp. (Hansen, 1890), Caligus acanthopagri (Lin, Ho and Chen, 1994), Gnathiidae indet. (Leach, 1814), Isopoda indet. (Latreille, 1817)], four Nematoda taxa [Hysterothylacium sp. (Ward and Magath, 1917), Philometra epinepheli (Dewi and Palm, 2013), Philometra sp. (Costa, 1845), Nematoda indet.], three Digenea taxa (Cainocreadium epinepheli (Durio and Manter, 1968, Gyliauchen cf. nahaensis [Ozaki, 1937, Prosorhynchus sp. (Odhner, 1907)] and one Monogenea taxon [Pseudorhabdosynochus sp. (Yamaguti, 1958)] were found.

Ectoparasites represented the most predominant parasite group in E. ongus. The isopods Alcirona sp. and Gnathiidae indet. had the highest prevalences of $50.0 \%$ and $43.0 \%$. Albeit a lower prevalence (23.3\%), the Monogenea Pseudorhabdosynochus $\mathrm{sp}$. had the highest mean abundance (5.4) and mean intensity (23.0) (Table 2). Fish which served as a host for this monogenean were highly infested (up to 83 worms per fish, Table 2).

With regard to endoparasites, the nematode Hysterothylacium sp. was the most common taxon with a prevalence 
Table 2 Parasites from 30 specimens of $E$. ongus from the Thousand Islands sampled in 2018, including prevalence $(\mathrm{P}(\%))$, intensity (I), mean intensity $(\mathrm{mI})$, mean abundance $(\mathrm{mA})$, and diversity indices

\begin{tabular}{|c|c|c|c|c|c|}
\hline Parasite/parasitological index & Stage & $\mathrm{P}(\%)$ & $\mathrm{mI}$ & (I) & $\mathrm{mA}$ \\
\hline \multicolumn{6}{|l|}{ Ectoparasites } \\
\hline Pseudorhabdosynochus sp. (M)*** & Adult & 23.3 & 23.0 & $2-83$ & 5.4 \\
\hline Alcirona sp. $(\mathrm{Cr})^{* * *}$ & Adult & 50.0 & 2.1 & $1-7$ & 1.0 \\
\hline Caligus acanthopagri $(\mathrm{Cr})^{*}$ & Adult & 16.7 & 1.0 & 2 & 0.2 \\
\hline Isopoda indet. (Cr) & Adult & 13.3 & 1.0 & $1-3$ & 0.1 \\
\hline Gnathiidae indet. $(\mathrm{Cr})^{* * *}$ & Larval & 43.3 & 1.4 & $1-3$ & 0.6 \\
\hline \multicolumn{6}{|l|}{ Endoparasites } \\
\hline Cainocreadium epinepheli (D)* & Adult & 10.0 & 4.3 & $1-8$ & 8.0 \\
\hline Gyliauchen cf. nahaensis (D)** & Adult & 16.7 & 1.6 & $1-4$ & 0.3 \\
\hline Prosorhynchus sp. (D)* & Larval & 6.7 & 1.0 & 1 & 0.1 \\
\hline Hysterothylacium $\mathrm{sp} .(\mathrm{N})^{* * *}$ & Larval & 20.0 & 1.5 & $1-3$ & 0.3 \\
\hline Philometra epinepheli $(\mathrm{N})^{* * *}$ & Adult & 3.3 & 1.0 & 1 & 0.0 \\
\hline Philometra sp. $(\mathrm{N})^{*}$ & Adult & 10.0 & 1.3 & $1-2$ & 0.1 \\
\hline Nematoda indet. $(\mathrm{N}) * * *$ & Larval & 3.3 & 2.0 & 1 & 0.1 \\
\hline \multicolumn{6}{|l|}{ Parasitological indices } \\
\hline Shannon-Wiener index of species diversity (total) & & 1.41 & & & \\
\hline Shannon-Wienerindex of species diversity (endoparasites) & & 0.54 & & & \\
\hline Berger-Parker index of dominance (total) & & 0.62 & & & \\
\hline Berger-Parker index of dominance (endoparasites) & & 0.33 & & & \\
\hline Pielou index of eveness (total) & & 0.57 & & & \\
\hline Pielou index of evenness (endoparasites) & & 0.28 & & & \\
\hline Ecto- to endoparasite ratio & & 0.71 & & & \\
\hline
\end{tabular}

$C r$ Crustacea, $D$ Digenea, $M$ Monogenea, $N$ Nematoda

* New host records for $E$. ongus

**New host record for epinephelids

***Also found in Karimunjawa (Neubert et al. [28]) of $20 \%$, followed by the digeneans Gyliauchen cf. nahaensis and Cainocreadium epinepheli with prevalences of $16 \%$ and $10 \%$, respectively. The digenean $\mathrm{Ca}$. epinepheli was the most abundant taxon in the present study (see Table 1). Gyliauchen cf. nahaensis (Table 3; Fig. 2), usually host specific to herbivorous fish (43), is herewith reported for the first time from an Epinephelus species.

Two taxa of Philometra were isolated from E. ongus, Philometra epinepheli (from the operculum) and Philometra sp. 1 (subcutaneous inside the mouth). The latter might represent a new species. It differed from already recorded Philometra species from groupers in Indonesia with two liplike structures at the mouth, a distinctively shaped swollen esophagus, a different body length and site of infection. So far, only three Philometra species have been recorded from E. ongus: P. epinepheli, $P$. cf. lateolabracis and P. ocularis [28]. Philometra sp. 1 differs from P. epinepheli by larger gravid females $(280 \mathrm{~mm}$ vs. $70-190 \mathrm{~mm}$ ) and a different infection site (subcutaneous at mouth vs. subcutaneous at operculum) [22, 28, 44]. Philometra sp. 1 differs from $P$. lateolabracis in morphology (shorter uterus, ovaries do not reach up to the nerve ring) and in infection site (subcutaneous at mouth vs. gonads) [28, 45-47]. Philometra sp.
1 differs from $P$. ocularis by the lack of four large fleshy anterior papillae, a round mouth and in infection site (subcutaneous at mouth vs. eye cavity) $[28,48]$. The herewith recorded Philometra sp. 1 shares most morphological characters (ovaries not reaching up to nerve ring, similar body length of $240 \mathrm{~mm}$, comparable swollen esophagus) with Philometra sp. found by Kleinertz [22] in E. coioides and E. areolatus, and by Rückert [21] in E. coioides and E. fuscoguttatus. In Kleinertz [22] Philometra sp. 2 infested the gonads, gills, gill cavity, mesentery, mouth cavity, nose cavity and opercula, whereas in Rückert [21] Philometra sp. 3infested the gills, gill cavity, mouth cavity and nose cavity. In both previous studies, Philometra sp. 2 and 3 were not found subcutaneous at the mouth.

The Berger-Parker index of dominance reached 0.62 when considering the total parasite fauna, but decreased to 0.3 for endoparasites only. The total parasite fauna had a high Shannon-Wiener index of diversity of 1.41. For only endoparasites, the Shannon-Wiener index decreased to 0.54 . This trend goes along with a Pielou index of evenness, which was 0.57 including the ectoparasites and decreased to 0.28 for only endoparasites. 
Table 3 Measurements of Gyliauchen cf. nahaensis from Epinephelus ongus from the Thousand Islands compared to data published by Yamaguti $[55]^{\mathrm{a}}$ and Nahhas and Wetzel $[59]^{\mathrm{b}}$

Fig. 2 Habitus of two specimens of Gyliauchen cf. nahaensis. Scale bars a $0.2 \mathrm{~mm}$, b $0.25 \mathrm{~mm}$. $C$ caeca, $C S$ cirrus sack, $E D$ ejaculatory duct, $O e$ esophagus, $O e B$ esophagus bulb $O$ ovary, $P h$ pharynx, $T$ testes, $V$ vitellarium, $V S$ ventral sucker

\begin{tabular}{|c|c|c|c|c|c|c|}
\hline \multirow{5}{*}{$\begin{array}{l}\text { Host } \\
\text { Site of infection } \\
\text { Locality } \\
\text { Physiological feature }\end{array}$} & \multirow{2}{*}{\multicolumn{2}{|c|}{$\frac{\text { Gyliauchen } \text { cf. nahaensis }}{\text { Epinephelus ongus }}$}} & \multirow{2}{*}{\multicolumn{2}{|c|}{$\frac{\text { Gyliauchen nahaensis }^{a}}{\text { Acanthurus } \mathrm{sp} .}$}} & \multicolumn{2}{|c|}{ Gyliauchen nahaensis $^{b}$} \\
\hline & & & & & Siganus pu & ctatus \\
\hline & \multicolumn{2}{|l|}{ Gills } & \multicolumn{2}{|l|}{ Intestine } & \multicolumn{2}{|l|}{ Intestine } \\
\hline & \multicolumn{2}{|c|}{$\begin{array}{l}\text { Thousand Islands, Indo- } \\
\text { nesia }\end{array}$} & \multicolumn{2}{|c|}{ Makassar, Indonesia } & \multicolumn{2}{|l|}{ Suva, Fiji } \\
\hline & $\mathrm{mm}$ & $\begin{array}{l}\text { Percent of } \\
\text { body length }\end{array}$ & $\mathrm{mm}$ & $\begin{array}{l}\text { Percent of } \\
\text { body length }\end{array}$ & $\mathrm{mm}$ & $\begin{array}{l}\text { Percent of } \\
\text { body length }\end{array}$ \\
\hline Body L & $0.94-1.67$ & & $1.65-2.40$ & & $1.30-2.45$ & \\
\hline Body W & $0.28-0.56$ & 30.3 & $0.58-0.75$ & 32.8 & $0.70-1.13$ & 48.8 \\
\hline Oral sucker L & $0.14-0.24$ & 14.5 & $0.13-0.19$ & 7.9 & $0.20-0.28$ & 12.8 \\
\hline Oral sucker W & $0.11-0.18$ & 10.6 & $0.10-0.15$ & 6.2 & $0.17-0.24$ & 10.9 \\
\hline Pharynx L & $0.14-0.22$ & 13.6 & $0.15-0.25$ & 9.9 & $0.22-0.39$ & 16.3 \\
\hline Pharynx W & $0.11-0.18$ & 10.5 & $0.13-0.30$ & 10.6 & $0.18-0.28$ & 12.3 \\
\hline Ventral sucker L & $0.18-0.32$ & 18.5 & $0.25-0.36$ & 15.1 & $0.27-0.43$ & 18.7 \\
\hline Ventral sucker W & $0.17-0.32$ & 18.8 & - & - & $0.26-0.45$ & 18.9 \\
\hline Ovary L & 0.07 & 5.7 & $0.06-0.11$ & 4.2 & $0.08-0.20$ & 7.5 \\
\hline Ovary W & 0.06 & 4.4 & $0.06-0.10$ & 4.0 & $0.07-0.15$ & 5.9 \\
\hline Eggs L & $0.06-0.07$ & 5.2 & 0.08 & 4.0 & $0.06-0.08$ & 3.7 \\
\hline Eggs W & $0.03-0.04$ & 2.7 & $0.04-0.05$ & 2.2 & $0.04-0.06$ & 2.7 \\
\hline Testes L & $0.21-0.23$ & 16.9 & $0.11-0.23$ & 8.4 & $0.18-0.33$ & 13.6 \\
\hline Testes W & $0.21-0.21$ & 16.3 & $0.10-0.20$ & 7.4 & $0.13-0.33$ & 12.3 \\
\hline
\end{tabular}

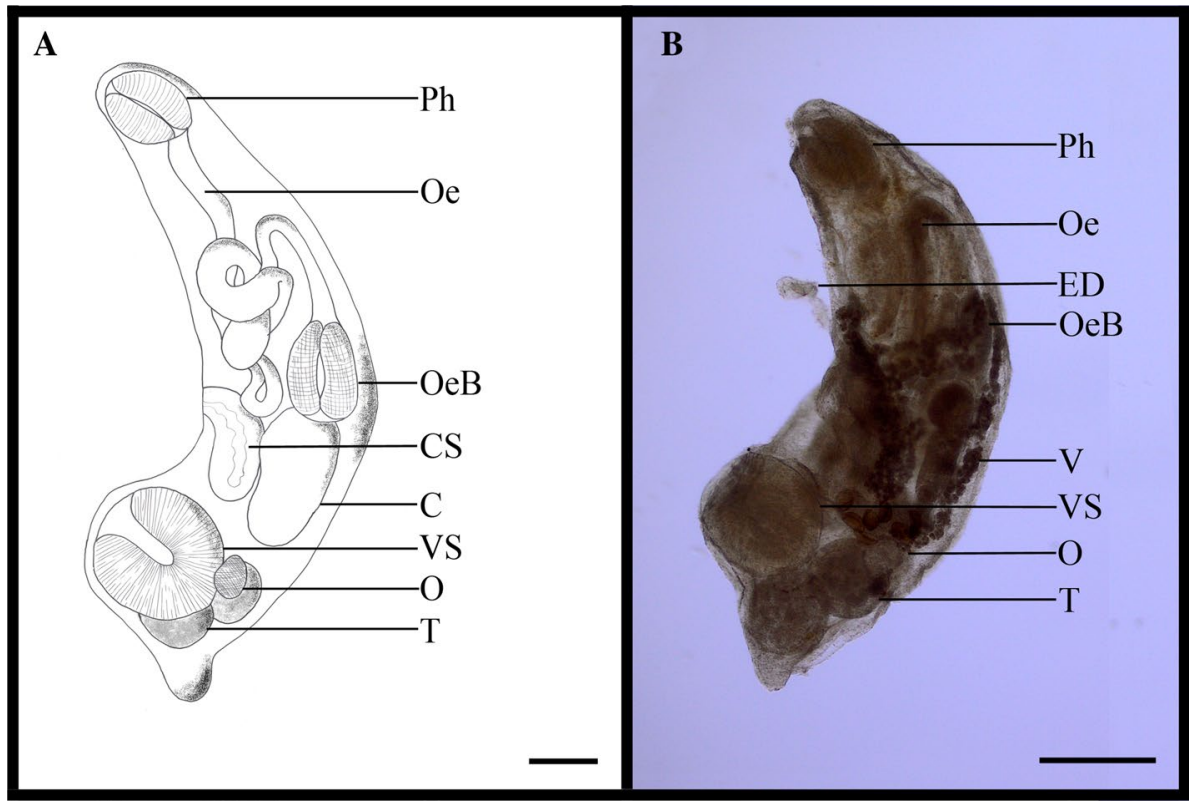

\section{Comparison of Epinephelus ongus from the Thousand Islands and Karimunjawa}

A combination of both data sets resulted in a total of 23 parasite taxa (17 in Karimunjawa and 12 in Thousand Islands) for E. ongus from Indonesia, 6 of them recorded for both locations (Table 2). The MDS plot based on parasite abundances shows that the infection patterns at both localities were distinctively grouped (999 permutations) (Fig. 3). The data support a significant difference between both sampling sites (ANOSIM: $R=0.527, p<0.05$ ), although some samples of Karimunjawa and the Thousand Islands overlap. The major taxa contributing to the separation of the two localities were the gill monogeneans Pseudorhabdosynochus quadratus and the crustaceans Caligus sp. found in Karimunjawa (SIMPER Analysis). 
Fig. 3 MDS plot of the parasite fauna from Epinephelus ongus in Karimunjawa and the Thousand Islands based on parasite abundances. Data from Karimunjawa according to Neubert et al. [28]

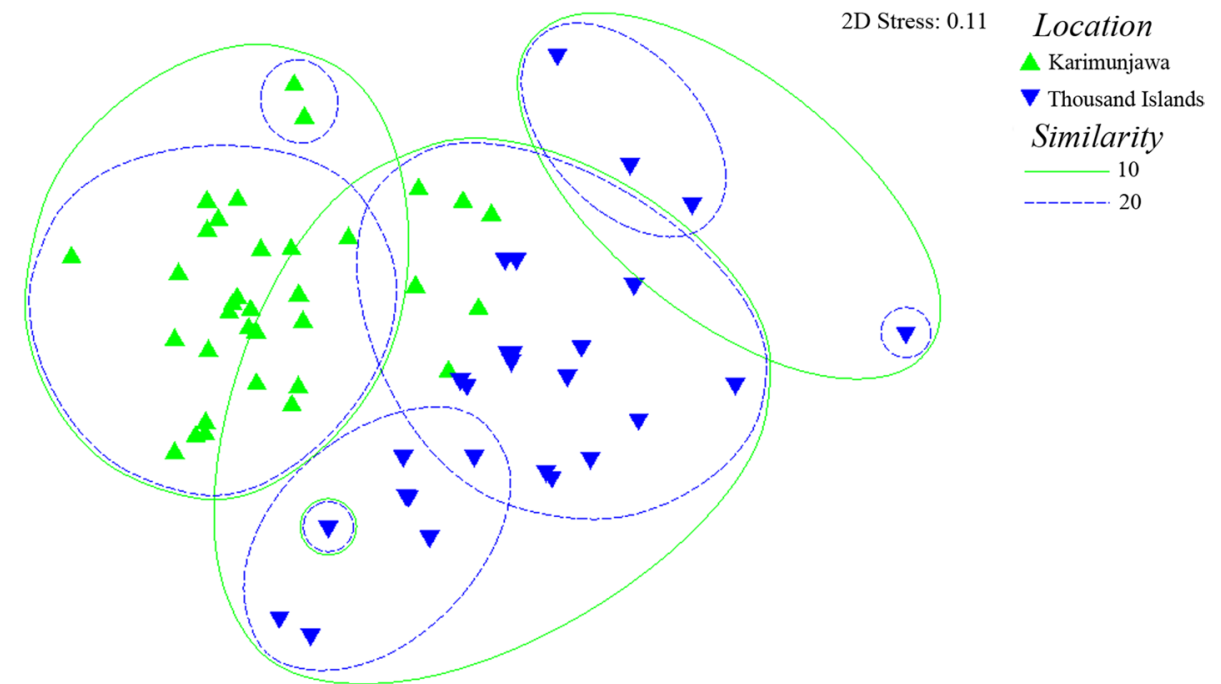

\section{Discussion}

\section{Parasite Records}

The present study extends our knowledge on the parasite fauna of $E$. ongus by $21 \%$. Five new host and five new locality records were established, with the digeneans Cainocreadium epinepheli and Prosorhynchus sp., the nematode Philometra sp. and the copepod Caligus acanthopagri reported for the first time from E. ongus and the digenean Gyliauchen cf. nahaensis for the first time in Epinephelus. Additionally, the Thousand Islands represent a new locality record for G. cf. nahaensis, Philometra epinepheli, Philometra sp., C. acanthopagri and Ca.epinepheli. To date, seven earlier studies investigated the parasite fauna of the whitestreaked grouper, two without any parasite records [32, 36], three reporting one parasite species $[31,33,35]$ and two from Indonesia with 17 and eight taxa, respectively [28, 34]. Though Stolz [34] focused on ectoparasites only, the latter findings suggest that the parasite load in white-streaked groupers from Indonesia underlies considerable variability in the number of isolated parasite species.

Ectoparasites predominated the parasite fauna of E. ongus and the most abundant and prevalent one was the monogenean Pseudorhabdosynochus sp. Parasites of this genus are usually host specific and very common in groupers [49] with $P$. quadratus having been described from $E$. ongus from New Caledonia in the past [33]. The high infestation of these diplectanid monogeneans coincides with findings of other studies [28, 33, 34]. Another generalist was the ectoparasite Alcirona sp. which has already been recorded from, e.g., $E$. areolatus, E. coioides, E. fuscoguttatus, E. quoyanus and Variola albimarginata. Caligus spp. also infected E. areolatus, E. coioides, E. corallicola, E. quoyanus and V. albimarginata in Indonesia [28, 34].
Most of the isolated endoparasites have already been found in other serranids in Indonesian waters, e.g., Ca. epinepheli, Philometra spp., Hysterothylacium sp. or Prosorhynchus sp. [19-22, 25, 26, 34]. With three Philometra species so far isolated from E. ongus, this genus is also present in E. areolatus, E. coioides and E. fuscoguttatus and commonly infects groupers [28, 50]. In addition, the record of Philometra sp. that is suggested to represent a new species and awaits description adds to this biodiversity in groupers [21, 22, 44]. New specimen collections from E.ongus are required to confirm its real identity.

Here, similar to earlier studies of $E$. ongus, we did not find any anisakid nematodes and only Neubert et al. [28] reported Anisakis typica at a low prevalence of $2.9 \%$. No nematodes infected the musculature, where the possible parasite transmission of zoonotic helminths to the consumer takes place. However, post-mortem migration of helminth larvae into the fillet can occur and Hysterothylacium sp. has caused zoonoses in the past, even though it originally infected the intestinal tract of host fishes [51]. With Hysterothylacium sp. larvae present in the studied white-streaked groupers, parasite-borne health risks should not be underestimated, but further studies are needed to better understandand evaluate the infection patterns of zoonotic parasites of E. ongus, which is a species of rising commercial interest.

With many parasite species having high host specificity to groupers, but a low host specifictiy within epinephelids, there is a risk of parasite transmission between $E$. ongus and its cogeners. This is problematic in and around mariculture facilities, especially under consideration of increasing mariculture activities throughout the region. Consequently, the recorded parasite taxa in this non-cultivated grouper species might still lead to future economic losses $[52,53]$ in maricultured fish and also impacting wild fish stocks. 


\section{Ecological Parameters}

The parasite fauna was predominated by the ectoparasite Pseudorhabdosynochus sp., implied by a Berger-Parker index of 0.62 for the total parasite fauna and a lower index of 0.3 for only endoparasites. Evenness and diversity indices were higher in the total parasite fauna compared with only endoparasites. Consequently, the taxa are more evenly distributed even when ectoparasites (including the dominant Pseudorhabdosynochus sp.) are considered. This can be explained from a relatively low amount of isolated endoparasites in E. ongus resulting in a very low Shannon-Wiener index of 0.54 , compared to other grouper species $(E$. coioides up to 1.84, 20, E. fuscoguttatus). Both larger sized species have been sampled in more detail with up to 420 specimens per study e.g., [21, 22].

Differences in diet and habitat most likely result in the observed less diverse parasite fauna of E. ongus compared to other species [20, 24, 26]. Though diet and behavior of adult E. coioides, E. fuscoguttatus and E. ongus are approximately the same [54], the parasite composition is different [23, 24, 28]. Sampled specimens of E. coioides and E. fuscoguttatus often were juveniles, whereas our $E$. ongus were adults. Juvenile E. coioides and E. fuscoguttatus prefer more shallow waters and live over muddy bottoms, fine sediments or in seagrass beds [54, 55], while adult E. ongus live in deeper coral reef habitats and rocky bottoms, often in caves in up to $60 \mathrm{~m}$ depth $[27,55]$. The different ecology, size and age of juvenile and adult E. coioides and E. fuscoguttatus favor a broad accumulation of parasites, which leads to a diverse and species-rich parasite fauna. Until 2016, 57 different parasite species have been recorded in, e.g., E. coioides [22, 26], and even from highly polluted regions around Jakarta Bay up to 31 parasite species were found [20]. This differs from $E$. ongus, with only 30 recorded parasite species so far. Neubert et al. [28] isolated only 17 species in E. ongus in Karimunjawa, a region where the biodiversity is believed to be particularly high $[28,29]$, suggesting that the observed differences in parasite diversity are real and not caused by biased sampling.

An interesting finding was the digenean Gyliauchen cf. nahaensis in E. ongus (Gyliauchenidae, Fig. 2; Table 2). This genus has been recorded in Indonesia only three times, in Sulawesi and Bali $[14,56]$ in herbivorous reef fish. Gyliauchenid trematodes infect the intestine of their hosts in the Indo-West Pacific [57] and have almost exclusively been recorded from fishes from the herbivorous families Acanthuidae, Chaetodontidae, Pomacanthidae, Scaridae, Siganidae and Zanclidae [43, 58]. However, Srivastava [59] described the species G. ozakii from the intestine of the carnivorous predator Harpodon nehereus in the Arabian Sea [60]. Lopez [61] isolated Gyliauchen sp. from the carnivorous grouper Plectropomus leopardus in the Philippines. Here, the finding of $G$. cf. nahaensis in the gills of carnivorous E. ongus likely depicts an accidental infection, because this genus is very host specific and highly adapted to herbivorous fish [43]. Nevertheless, $G$. cf. nahaensis is a rare parasite in Indonesian waters and our findings reflect parasitogical research potential in this region.

\section{Regional Differences}

The herewith analyzed fish specimens from the two archipelagos were similar in size and weight (Table 2). Size is an important factor for comparability because larger fish often have more endoparasites [26]. The fish from the two locations differed in sex ratio (Table 2, more males in Karimunjawa, more females in the Thousand Islands), but there is no consistency in the literature how or if sex affects parasite abundance in groupers. Samples were obtained 5 years apart: Karimunjawa in 2013 [28] and Thousand Islands in 2018. While pollution and anthropogenic effects can have an impact on the fish parasite fauna of groupers [20], previous studies in Indonesia have shown that seasonal change and natural inter-annual variability seem to have low impact on the metazoan fish parasite fauna [23, 26]. Therefore, we conclude that the samples were comparable and we suggest that the significant differences in the parasite abundances of E. ongus seen in the MDS plot (Fig. 3) are mainly caused by different biotic and abiotic conditions at both sites and are not biased by annual change or host factors.

While the MDS plot shows a clear separation of samples, some fish from Karimunjawa and the Thousand Islands are grouped together. Most likely this is because these samples harbored identical parasite species, as the locations share six common parasite species. This minor overlap in parasite abundance is not very surprising because we sampled the same species in a quite similar habitat—but it is all the more interesting to observe a significant difference in infection patterns in white-streaked groupers based on the sample location. The ectoparasites Pseudorhabdosynochus quadratus and Caligus sp. from Karimunjawa were the main factors for the discrepancies. Some gill parasites are thought to accumulate over time, depending on the age of the fish [28]. However, no significant differences in the total fish length between both sites could be detected (Student's $T$ test: $p=0.719$ ). Despite high monogenean infestation, Karimunjawa is considered a healthy marine ecosystem due to high endoparasite diversity, high diversity indices and low ecto- to endoparasite ratios $[28,42]$. While both localities are important spawning and nursery grounds for groupers $[62,63]$, Karimunjawa has established management plans, fishing guidelines and protected zones for grouper [29]. Grouper abundance might be higher there which might result in higher ectoparasite transmission and lead to higher ectoparasite infestation in this region. 
E. ongus from Karimunjawa harbored one single Digenea species, whereas E. ongus from the Thousand Islands harbored three. The first intermediate hosts of this parasite group are gastropods. Yulianto [64] reported a sharp decrease of clams in Karimunjawa between 2005 and 2009, possibly linked to increased water pollution from coastal development [65] which may have also affected gastropod abundance. In Jakarta Bay, mollusk abundance decreased over seven decades due to anthropogenic pollution [66]. Finding three digenean taxa in the Thousand Islands suggests that pollution diluted from Jakarta Bay toward the more remote Thousand Islands [66], resulting in a sufficient gastropod abundance for the parasites to complete their life cycles.

\section{Conclusion}

The present study suggests that the parasite fauna of the small-sized white-streaked grouper has less species diversity compared to its larger sized cogeners. Its parasite community differed between the Thousand Islands and Karimujawa archipelagos shown in a comparison between samples from 2013 by Neubert et al. [28] and 2018. This is due to the differences in habitats and regional differences, leading to different ecological needs of the fishes which implies that the parasite composition of $E$. ongus can indicate different populations at the two sites. Fishing efforts on E. ongus is steadily increasing and threatens their occurrence throughout the Indonesian archipelago in recent years. This study suggests that the fish parasite community can indicate different origin of groupers and possibly distinct populations, supporting the development of better monitoring and management plans for this species in future. Finding numerous new host and locality records and parasites with a certain affinity to groupers, we suggest potential risks of parasite transmission within different grouper species, for example those cultivated in mariculture facilities or free living groupers. While this poses food safety concerns to consumers of fisheries and aquaculture products in Indonesia, increasing fishing efforts on E. ongus call for more research on this grouper species and better monitoring and management plans are needed.

Acknowledgements We want to thank the Brede Foundation Bremen for funding the travel and the sample collection in Indonesia. Samples were taken under MoU between IPB Agricultural University Bogor and University Rostock and are now deposited at the Indonesian Institute of Science (LIPI) in Bogor. For assisting in sample deposit and registration at LIPI, we thank Dr. Kartika Dewi and Gloria Animalesto. We also thank Intan Destianis Hartati for assisting in sample collection. Lastly, we would like to acknowledge Dr. Ir. Luky Adrianto (Dean of the Faculty Fisheries and Marine Sciences, FPIK-IPB University, Bogor) for providing laboratory space and materials.
Author Contribution SK: sampling organisation, laboratory work and analysis for parasite identification, writing, correction and editing of manuscript. SN: providing laboratory space, correction of manuscript. HWP: providing laboratory space and materials, especially genetic analyses, correction of manuscript. ST: supporting laboratory work and parasite identification, correction of manuscript. CW: supporting and securing funding, correction of manuscript. IY: supporting sample collection and data analysis, correction of manuscript. SK: research idea, providing laboratory space materials and equipment, supporting sample collection, laboratory work, data analyses and parasite identification, correction and improvement of manuscript.

Funding Open Access funding enabled and organized by Projekt DEAL. Financial support was provided by the Brede Foundation Bremen, Germany for traveling and sampling costs.

Availability of Data and Materials If wanted, we can share our raw data.

Code Availability Not applicable.

\section{Compliance with Ethical Standards}

Conflict of Interest On behalf of all authors, the corresponding author states that there is no conflict of interest or competing interests.

Ethics Approval The research was conducted under collaboration between IPB University (Bogor Agricultural University) and University of Rostock (under existing MoU).

Consent to Participate Not applicable.

Consent for Publication Not applicable.

Open Access This article is licensed under a Creative Commons Attribution 4.0 International License, which permits use, sharing, adaptation, distribution and reproduction in any medium or format, as long as you give appropriate credit to the original author(s) and the source, provide a link to the Creative Commons licence, and indicate if changes were made. The images or other third party material in this article are included in the article's Creative Commons licence, unless indicated otherwise in a credit line to the material. If material is not included in the article's Creative Commons licence and your intended use is not permitted by statutory regulation or exceeds the permitted use, you will need to obtain permission directly from the copyright holder. To view a copy of this licence, visit http://creativecommons.org/licenses/by/4.0/.

\section{References}

1. Harris E (2001) Status of Indonesian fisheries today and the research needed. In Proceedings of the JSPS-DGHE International Symposium on Fisheries Science in tropical area. Faculty of Fisheries and Marine Science-IPB Bogor-Indonesia 62-66

2. Tran N, Rodriguez UP, Chan CY, Phillips MJ, Mohan CV, Henriksson PJG, Koeshendrajana S, Suri S, Hall S (2017) Indonesian aquaculture futures: an analysis of fish supply and demand in Indonesia to 2030 and role of aquaculture using the AsiaFish model. Mar Policy 79:25-32. https://doi.org/10.1016/j.marpo 1.2017.02.002

3. World Health Organization (2018) The state of food security and nutrition in the world 2018: building climate resilience for food security and nutrition. Food and Agriculture Organizsation 
4. Afero F, Miao S, Perez AA (2010) Economic analysis of tiger grouper Epinephelus fuscoguttatus and humpback grouper Cromileptes altivelis commercial cage culture in Indonesia. Aquacult Int 18(5):725-739. https://doi.org/10.1007/s10499-009-9295-x

5. Yulianto I, Hammer C, Wiryawan B, Palm HW (2019) Costbenefits of grouper Epinephelus fuscoguttatus (Forsskål, 1775) stock enhancement and sea-ranching in Indonesia. Asian Fish Sci 32(3):124-130

6. Sadovy de Mitcheson YJ, Linardich C, Barreiros JP, Ralph GM, Aguilar-Perera A, Afonso P, Erisman BE, Pollard DA, Fennessy ST, Bertonconi AA, Nair RJ, Rhodes KL, Francour P, Brulé T, Samoilys MA, Ferreira BP, Craig MT (2020) Valuable but vulnerable: over-fishing and under-management continue to threaten groupers so what now? Mar Policy 116:103909. https://doi. org/10.1016/j.marpol.2020.103909

7. Sadovy de Mitcheson YJ, Craig MT, Bertoncini AA, Carpenter KE, Cheung WL, Choat JH, Cornish AS, Fennessy ST, Ferreira BP, Heemstra PC, Liu M, Myers RF, Pollard DA, Rhodes KL, Rocha LA, Russell BC, Samoilys MA, Sanciangco J (2013) Fishing groupers towards extinction: a global assessment of threats and extinction risks in a billion dollar fishery. Fish Fish 14(2):119-136. https://doi.org/10.1111/j.1467-2979.2011.00455 .X

8. Khasanah M, Nurdin N, Sadovy de Mitcheson Y, Jompa J (2020) Management of the grouper export trade in Indonesia. Rev Fish Sci Aquacult 28(1):1-15. https://doi.org/10.1080/23308 249.2018.1542420

9. Poulin R, Morand S (2000) The diversity of parasites. Q Rev Biol 75(3):277-293. https://doi.org/10.1086/393500

10. Slifko TR, Smith HV, Rose JB (2000) Emerging parasite zoonoses associated with water and food. Int J Parasitol 30(12-13):1379_ 1393. https://doi.org/10.1016/S0020-7519(00)00128-4

11. Klimpel S, Palm HW (2011) Anisakid nematode (Ascaridoidea) life cycles and distribution: increasing zoonotic potential in the time of climate change? In: Mehlhorn H (ed) Progress in Parasitology. Springer, Berlin, Heidelberg, pp 201-222

12. Kleinertz S (2017) Modern applications in terms of biological indication, health of aquatic organisms and ecosystems. Cumulative Habilitation thesis, University of Rostock

13. Palm HW, Theisen S, Damriyasa IM, Oka IBM, Suratma A, Wibowo S, Kusmintarsih ES, Setyowati EA, Kleinertz S (2017) Anisakis Dujardin, 1845 (Nematoda: Ascaridoidea) from Indonesia. Dis Aquat Org 123(2):141-157. https://doi.org/10.3354/dao03 091

14. Theisen S (2020) Indonesian marine fish parasite biodiversity. Dissertation, University of Rostock

15. Ullah H, Nagelkerken I, Goldenberg SU, Fordham DA (2018) Climate change could drive marine food web collapse through altered trophic flows and cyanobacterial proliferation. PLoS Biol 16(1):e2003446. https://doi.org/10.1371/journal.pbio.2003446

16. Champion C, Hobday AZ, Zhang X, Pecl GT, Tracey SR (2019) Changing windows of opportunity: past and future climate-driven shifts in temporal persistence of kingfish (Seriola lalandi) oceanographic habitat within south-eastern Australian bioregions. Mar Freshw Res 70(1):33-42. https://doi.org/10.1071/MF17387

17. Marcogliese DJ, Scholz T (1999) Recent visitations by eels to Sable Island, Canada, confirmed by parasites. J Fish Biol 54(3):685-687. https://doi.org/10.1111/j.1095-8649.1999.tb006 46.x

18. Klimpel S, Rückert S (2005) Life cycle strategy of Hysterothylacium aduncum to become the most abundant anisakid fish nematode in the North Sea. Parasitol Res 97(2):141-149. https://doi. org/10.1007/s00436-005-1407-6

19. Palm HW, Rückert S (2009) A new approach to visualize ecosystem health by using parasites. Parasitol Res 105(2):539. https:// doi.org/10.1007/s00436-009-1423-z
20. Neubert K, Yulianto I, Theisen S, Kleinertz S, Palm HW (2016) Parasite fauna of Epinephelus coioides (Hamilton, 1822) (Epinephelidae) as environmental indicator under heavily polluted conditions in Jakarta Bay, Indonesia. Mar Poll Bull 110(2):747_ 756. https://doi.org/10.1016/j.marpolbul.2016.02.07

21. Rückert S (2006) Marine fischparasiten in Indonesien: Befallssituation und Bedeutung für die Marikultur von Zackenbarschen. Dissertation, University of Duesseldorf

22. Kleinertz S (2010) Fish parasites as bioindicators: environmental status of coastal marine ecosystems and a grouper mariculture farm in Indonesia. Dissertation, University of Bremen

23. Rückert S, Klimpel S, Palm HW (2010) Parasites of cultured and wild brown-marbled grouper Epinephelus fuscoguttatus (Forsskål, 1775) in Lampung Bay, Indonesia. Aquacult Res 41(8):11581169. https://doi.org/10.1111/j.1365-2109.2009.02403.x

24. Palm HW (2011) Fish parasites as biological indicators in a changing world: Can we monitor environmental impact and climate change? In: Mehlhorn H (ed) Progress in Parasitology. Springer, Berlin, Heidelberg, pp 223-250

25. Kleinertz S, Damriyasa M, Hagen W, Theisen S, Palm HW (2014) An environmental assessment of the parasite fauna of the reefassociated grouper Epinephelus areolatus from Indonesian waters. J Helminthol 88:50-63. https://doi.org/10.1017/S0022149X1 2000715

26. Kleinertz S, Palm HW (2015) Parasites of the grouper fish Epinephelus coioides (Serranidae) as potential environmental indicators in Indonesian coastal ecosystems. J Helminthol 89(1):86-99. https://doi.org/10.1017/S0022149X1300062X

27. Craig MT (2007) Preliminary observations on the life history of the white-streaked grouper, Epinephelus ongus, from Okinawa, Japan. Ichthyol Res 54(1):81-88. https://doi.org/10.1007/s1022 8-006-0377-8

28. Neubert K, Yulianto I, Kleinertz S, Theisen S, Wiryawan B, Palm HW (2016) Parasite fauna of white-streaked grouper, Epinephelus ongus (Bloch, 1790) (Epinephelidae) from Karimunjawa, Indonesia. Parasitol Open 2(e12):1-11. https://doi.org/10.1017/ pao.2016.6

29. Yulianto I, Hammer C, Wiryawan B, Palm HW (2015) Fishinginduced groupers stock dynamics in Karimunjawa, Indonesia. Fish Sci 81(3):417-432. https://doi.org/10.1007/s12562-015-0863-x

30. Neubert K (2018) Parasiten von Zackenbarschen als biologische Indikatoren in Südostasien: anthropogene Verschmutzung und Aquakulturverfahren. Dissertation, University of Rostock

31. Bray RA, Cribb TH, Barker SC (1996) Diploproctodaeinae (Digenea: Lepocreadiidae) from the coastal fishes of Queensland, Australia, with a review of the subfamily. J Nat Hist 30(3):317-366. https://doi.org/10.1080/00222939600770191

32. Nolan MJ, Cribb TH (2004) Two new blood flukes (Digenea: Sanguinicolidae) from Epinephelinae (Perciformes: Serranidae) of the Pacific Ocean. Parasitol Int 53(4):327-335. https://doi. org/10.1016/j.parint.2004.05.002

33. Schoelinck C, Justine JL (2011) Pseudorhabdosynochus quadratus n. sp. (Monogenea: Diplectanidae) from the white-streaked grouper Epinephelus ongus (Bloch) (Perciformes: Serranidae) off New Caledonia. Syst Parasitol 79(1):77. https://doi.org/10.1007/ s11230-011-9295-X

34. Stolz H (2017) Makroskopisch sichtbare Parasitenarten kommerzieller Zackenbarsche von Bali, Indonesien: Konsequenzen für Vermarktung und Aufzucht in der Aquakultur. MSc Thesis, University of Rostock

35. Shamsi S, Chen Y, Poupa A, Ghadam M, Justine JL (2018) Occurrence of anisakid parasites in marine fishes and whales off New Caledonia. Parasitol Res 117(10):3195-3204. https://doi. org/10.1007/s00436-018-6018-0

36. Santos TRN, Sikkel PC (2019) Habitat associations of fish-parasitic gnathiid isopods in a shallow reef system in the central 
Philippines. Mar Biodiv 49(1):83-96. https://doi.org/10.1007/ s12526-017-0756-6

37. Riemann F (1988) Nematoda: Introduction to the study of meiofauna. Smithsonian Institute Press, Washington DC

38. Bush AO, Lafferty KD, Lotz JM, Shostak AW (1997) Parasitology meets ecology on its own terms: Margolis et al. revisited. J Parasitol 83(4):75-583. https://doi.org/10.2307/3284227

39. Shannon CE (1948) A mathematical theory of communication. Bell Syst Tech J 27(3):379-423. https://doi. org/10.1002/j.1538-7305.1948.tb01338.x

40. Pielou DP, Matthewman WG (1966) The fauna of Fomes fomentarius (Linnaeus ex Fries) Kickx growing on dead birch in Gatineau Park, Quebec. Can Entomol 98(12):1308-1312. https ://doi.org/10.4039/Ent981308-12

41. Berger WH, Parker FL (1970) Diversity of planktonic foraminifera in deep-sea sediments. Science 168(3937):1345-1347. https://doi. org/10.1126/science.168.3937.1345

42. Rückert S, Klimpel S, Al-Quraishy S, Mehlhorn H, Palm HW (2009) Transmission of fish parasites into grouper mariculture (Serranidae: Epinephelus coioides (Hamilton, 1822)) in Lampung Bay, Indonesia. Parasitol Res 104(3):523. https://doi.org/10.1007/ s00436-008-1226-7

43. Jones A, Bray RA, Gibson DI (2005) Keys to the Trematoda. Natural History Museum, London

44. Dewi K, Palm HW (2017) Philometrid nematodes (Philometridae) of marine teleosts from Balinese waters, Indonesia, including the description of Philometra damriyasai sp. nov. Zootaxa 4341(4):577-584. https://doi.org/10.11646/zootaxa.4341.4.10

45. Moravec F, Justine JL (2002) On two species of Philometra (Nematoda, Philometridae) from the serranid fish Epinephelus septemfasciatus in Japan. Acta Parasitol 34-40

46. Moravec F, Glamuzina B, Marino G, Merella P, Di Cave D (2003) Occurrence of Philometra lateolabracis (Nematoda: Philometridae) in the gonads of marine perciform fishes in the Mediterranean region. Dis Aquat Org 53(3):267-269. https://doi. org/10.3354/dao053267

47. Quiazon KMA, Yoshinaga T, Ogawa K (2008) Taxonomical study into two new species of Philometra (Nematoda: Philometridae) previously identified as Philometra lateolabracis (Yamaguti, 1935). Folia Parasitol 55(1):29-41

48. Moravec F, Justine JL (2005) Two species of Philometra (Nematoda, Philometridae) from serranid fishes off New Caledonia. Acta Parasitol 50(4):323-331

49. Justine JL, Sigura A (2007) Monogeneans of the malabar grouper Epinephelus malabaricus (Perciformes, Serranidae) off New Caledonia, with a description of six new species of Pseudorhabdosynochus (Monogenea: Diplectanidae). Zootaxa 1543:1-44

50. Moravec F (2006) Dracunculoid and anguillicoloid nematodes parasitic in vertebrates. Academia, Prague

51. Shamsi S, Steller E, Chen Y (2018) New and known zoonotic nematode larvae within selected fish species from Queensland waters in Australia. Int J Food Microbiol 272:73-82. https://doi. org/10.1016/j.ijfoodmicro.2018.03.007

52. Tucker CS, Sommerville C, Wootten R (2002) Does size really matter? Effects of fish surface area on the settlement and initial survival of Lepeophtheirus salmonis, an ectoparasite of Atlantic salmon Salmo salar. Dis Aquat Org 49(2):145-152. https://doi. org/10.3354/dao049145
53. Ogawa K (2015) Diseases of cultured marine fishes caused by Platyhelminthes (Monogenea, Digenea, Cestoda). Parasitol 142(1):178-195. https://doi.org/10.1017/S0031182014000808

54. Heemstra PC, Randall JE (1993) FAO Species Catalogue: Groupers of the world (family Serranidae, subfamily Epinephelinae). An annotated and illustrated catalogue of the grouper, rockcod, hind, coral grouper and lyretail species known to date. FAO Fish Synop 125(16):382

55. Froese R, Pauly D (2020) FishBase. http://www.fishbase.org. Accessed 23 Apr 2020

56. Yamaguti S (1953) Parasitic worms mainly from Celebes. Part 3. Digenetic trematodes of fishes 2. Acta Med Okayama 8(3):258 295. https://doi.org/10.18926/AMO/31875

57. Al-Jahdali MO, Hassanine RES (2012) The life cycle of Gyliauchen volubilis Nagaty, 1956 (Digenea: Gyliauchenidae) from the Red Sea. J Helminthol 86(2):165-172. https://doi. org/10.1017/S0022149X11000186

58. Bray R, Waeschenbach A, Cribb T, Weedall G, Dyal P, Littlewood D (2009) The phylogeny of the Lepocreadioidea (Platyhelminthes, Digenea) inferred from nuclear and mitochondrial genes: Implications for their systematics and evolution. Acta Parasitol 54(4):310-329. https://doi.org/10.2478/s11686-009-0045-z

59. Srivastava HD (1938) Studies on the amphistomatous parasites of Indian food fishes. Part 2. A new trematode of the genus Gyliauchen Nicoll from an Indian marine fish. Indian J Vet Sci Anim Husb 8(4):399-401

60. Nahhas FM, Wetzel JA (1995) Digenetic trematodes of marine fishes from Suva, Fiji: The family Gyliauchenidae Ozaki, 1933. J Helminthol Soc Washington 62(2):117-130

61. Lopez NC (1998) Parasites of some serranid fishes from Manila Bay (Philippines). Philipp Sci 35:43-48

62. Hartoko A, Chayaningrum S, Febrianti DA, Ariyanto D (2015) Carbon biomass algorithms development for mangrove vegetation in Kemujan, Parang Island Karimunjawa National Park and Demak coastal area, Indonesia. Proc Environ Sci 23:39-47. https ://doi.org/10.1016/j.proenv.2015.01.007

63. Hidayati N, Suparmoko M (2018) Fish assemblage structure in relation to seagrass bed in Tidung Kecil Island, Kepulauan Seribu. E3S Web of Conferences 74:02005. https://doi.org/10.1051/e3sco nf/20187402005

64. Yulianto I, Kartawijaya T, Susanto HA, Cambell S (2010) The effectiveness of Karimunjawa. Proceeding of International Symposium on Small Islands and Coral Reefs

65. Campbell SJ, Kartawijaya T, Yulianto I, Prasetia R, Clifton J (2013) Co-management approaches and incentives improve management effectiveness in the Karimunjawa Park, Indonesia. Mar Policy 41:72-79. https://doi.org/10.1016/j.marpol.2012.12.022

66. van der Meij SE, Moolenbeek RG, Hoeksema BW (2009) Decline of the Jakarta Bay molluscan fauna linked to human impact. Mar Poll Bull 59(4-7):101-107. https://doi.org/10.1016/j.marpo lbul.2009.02.021

Publisher's Note Springer Nature remains neutral with regard to jurisdictional claims in published maps and institutional affiliations. 